ячменя / Е.М. Лисицын // Зернобобовые и крупяные культуры. - 2018. - № 2 (26). C. 66-71. DOI: 10.24411/2309-348X-2018-10019.

8. Shah K. Cadmium elevates level of protein, amino acids and alters activity of proteolytic enzymes in germinating rice seeds / K. Shah, R.S. Dubey // Acta Physiol. Plant. 1998. - V. 20, N. 2. - P. 189-196.

9. Холодова В. П. Адаптация к высоким концентрациям солей меди и цинка растений хрустальной травки и возможность их использования в целях фиторемедиации / В.П. Холодова, К.С. Волков, В.В. Кузнецов // Физиология растений. - 2005. - Т. 52, № 6. - C. 848-858.

10. Navacode S. A genetic analysis of aluminium tolerance in cereals / S. Navacode, A. Weidner, R. K. Varshney, U. Lohwasser, U. Scholz, M.S. Roder, A. Borner // Agric. Conspec. Sci. - 2010. - V. 75. - No. 4. - P. 191-196.

DOI 10.18699/GPB2020-110

\title{
Урожайность сортов овса в контрастных гидротермических условиях Приобской лесостепи
}

Сотник А.Я., к.с.-х.н., в.н.с., Костикова И.В., н.с.

Сибирский научно-исследовательский институт растениеводства и селекичии - филиал Института цฺитологии и генетики СО РАН, Новосибирская область, пос. Краснообск.

*e-mail:sibniirs@bk.ru

Исследования проводили в СибНИИРС - филиале ИЦиГ СО РАН в 2006-2019 гг. Материалом исследований явились 3 сорта овса селекиии СибНИИРС: Новосибирский 5, Новосибирский 88, Ровесник из питомника сибирского генофонда. Цель исследования - оценить сорта овса по способности формировать урожай в контрастных гидротермических условиях Приобской лесостепи Новосибирской области. Показано, что при распределении условий года на группы недостаточно использование только показателя ГТК за период развития растений. Отмечена сортовая специфичность по реализачии потенциала урожайности в разных гидротермических условиях. Сорт Новосибирский 88 относится к интенсивному типу, а сорт Новосибирский 5 - к экстенсивному типу.

Ключевые слова: овес, сорт, гидротермический коэффициент, урожайность.

\section{Yield varieties yield under contrast hydrothermal conditions of the forest steppe of the $\mathrm{Ob}$ region}

Sotnik A.YA. Candidate of Agricultural Sciences, Leading Researcher Kostikova I.V., Researcher

Siberian Research Institute of Plant Production and selection - branch of the Institute of Cytology and Genetics of the SB RAS, Novosibirsk Region, Krasnoobsk. 
e-mail: sibniirs@bk.ru

The study was carried out at SibRIPP\&B - branch ICG SB RAS in 20062019. The research material was 3 varieties of oats from SibNIIRS selection: Novosibirsk 5, Novosibirsk 88, the same age as the nursery of the Siberian gene pool. The analysis of yield and the main economically valuable traits of oats were carried out to determine the reaction of genotypes by their formation in years, contrasting in hydrothermal conditions (SCC).Varietal specificity was noted for the realization of the yield potential in different hydrothermal conditions. Variety Novosibirsk 88 is of the intensive type, and variety Novosibirsk 5 is of the extensive type. When distributing the conditions of the year into groups, it is not enough to use only the SCC indicator for the period of plant development.

Key words: oats, variety, hydrothermal coefficient, productivity.

Один из главных вопросов сельскохозяйственного производства стабилизация производства зерна по годам вне зависимости от изменения погодных условий. Решение этой проблемы в значительной степени зависит от использования генотипов с высоким потенциалом продуктивности $[1,2]$, устойчивых к действию абиотических и биотических стрессоров региона [3]. Почвенно-климатические условия зоны возделывания оказывают решающее влияние и на реализацию потенциальной продуктивности сорта.

Цель исследования - оценить сорта овса по способности формировать урожай в контрастных гидротермических условиях Приобской лесостепи Новосибирской области.

Методика исследований. Исследования проводили на опытном поле СибНИИРС, расположенном на расстоянии 5 км от р. п. Краснообск Новосибирского района Новосибирской области. Период изучения - с 2006 по 2019 гг. Агротехника при проведении опыта - общепринятая для зоны. Посев проводили сеялкой ССФК 7. Площадь делянки $2 \mathrm{~m}^{2}$, срок сева - преимущественно вторая декада мая. Норма высева - 5,5 млн. всхожих семян на гектар.

Материалом исследований явились 3 сорта овса селекции СибНИИРС - филиал ИЦиГ СО РАН: Новосибирский 5, Новосибирский 88, Ровесник из питомника демонстрационного сибирского генофонда. Сорта включены в группу сортового районирования при Государственном сортоиспытании по Новосибирской области [4]. Изучение сортов проводилось в соответствии с методическим указанием по изучению мировой коллекции ячменя, овса [5].

Метеорологические условия по данным метеорологической станции п. Огурцово в годы проведения исследований значительно различались по температурному фактору и по количеству осадков. Гидротермический коэффициент за период май - август (ГТК), показывающий соотношение количества осадков и суммы эффективных температур варьировал по годам от 0,59 до 3,17 . Количество осадков по годам так же изменялось в широких пределах (за май-июнь от 35 до 173 \%; за три месяца от 23 до 281 \%). 
Статистический анализ проведен по методике Б.А. Доспехова [6] с использованием стандартных компьютерных программ Microsoft Offise Excel.

Результаты исследований и их обсуждение.Для определения реакции сортов овса по формированию элементов продуктивности в контрастных гидротермических условиях, все года распределены на две группы по гидротермическому коэффициенту за период май-август. В первую группу вошли 2007, 2009, 2013, 2015, 2017, 2018 и 2019 гг., ГТК которых были в пределах 1,42 - 1,94. В эти годы за май и июнь выпадало 99 \% (2009 г.) $135 \%$ (2007 г.) от нормы осадков, а самые крайние показатели отмечены в 2019 г. - 81 \% и в 2018 г. - 173 \%. В этой группе выделяется 2013 г. не типичным ГТК $(3,17)$, который был обусловлен снижением температуры воздуха на 2 градуса относительно среднемноголетних данных, и большим количеством осадков за май-август (161 \% от нормы).

Во вторую группу вошли 2006, 2008, 2010, 2011, 2012, 2014 и 2016 гг., в которых ГТК был менее 1,42 . В эти годы за май и июнь выпадало $35 \%$ (2012 г.)-88 \% (2008 г.) осадков от нормы, только в 2006 г. - $116 \%$. Эти годы можно охарактеризовать как относительно, и как сильно засушливые. Необходимо отметить, что условия 2011 и 2016 гг. характеризовались весенней и летней засухой, за май-июнь выпало только 65 и 76 \% осадков от нормы, однако сорта в эти годы сформировали высокую урожайность благодаря равномерному распределению влаги по декадам.

В неблагоприятные годы недостаток влаги и высокие температуры воздуха в течение весенне-летнего периода значительно ускорили созревание растений и отрицательно сказались на зерновой продуктивности сортов.

По продолжительности вегетационного периода исследуемые сорта относятся к среднеранней группе спелости. Вариабельность продолжительности периода всходы - восковая спелость в обеих группах была незначительной, что обусловлено реакцией генотипов (таблица).

Таблициа - Сравнительная характеристика сортов овса по элементам урожайности

\begin{tabular}{|c|c|c|c|c|c|}
\hline \\
\hline $\begin{array}{c}\text { Группа } \\
\text { годов по } \\
\text { ГТК }\end{array}$ & Сорт & $\begin{array}{c}\text { Период } \\
\text { всходы - вос- } \\
\text { ковая спе- } \\
\text { лость, }(\mathrm{x} \pm \mathrm{Sx}) \\
\text { суток, } \mathrm{V} \%\end{array}$ & $\begin{array}{c}\text { Число } \\
\text { продуктив- } \\
\text { ных стеб- } \\
\text { лей, } \\
\text { (x } \pm \mathrm{Sx}) \\
\text { шт/м² }, \mathrm{V} \%\end{array}$ & $\begin{array}{c}\text { Вес зерна } \\
\text { с метелки, } \\
(\mathrm{x} \pm \mathrm{Sx}) \Gamma, \\
\mathrm{V} \%\end{array}$ & $\begin{array}{c}\text { Урожай- } \\
\text { ность, } \\
(x \pm \mathrm{Sx}) \\
\Gamma / \mathrm{M}^{2}, \mathrm{~V} \%\end{array}$ \\
\hline 1 & 2 & 3 & 4 & 5 & 6 \\
\hline \multirow{3}{*}{ 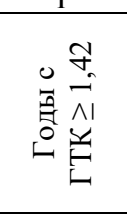 } & Новосибирский 5 & $\begin{array}{c}74,1 \pm 1,6 \\
V=5 \%\end{array}$ & $\begin{array}{l}530 \pm 30 * \\
V=12 \%\end{array}$ & $\begin{array}{l}1,3 \pm 0,1 \\
\mathrm{~V}=25 \%\end{array}$ & $\begin{array}{l}766 \pm 88 \\
V=28 \%\end{array}$ \\
\hline & Новосибирский 88 & $\begin{array}{c}75,7 \pm 1,6 \\
V=5 \%\end{array}$ & $\begin{array}{l}470 \pm 33 \\
V=12 \%\end{array}$ & $\begin{array}{c}1,4 \pm 0,1 \\
\mathrm{~V}=22 \%\end{array}$ & $\begin{array}{c}815 \pm 66 \\
V=20 \%\end{array}$ \\
\hline & Ровесник & $\begin{array}{c}75,8 \pm 1,5 \\
V=5 \%\end{array}$ & $\begin{array}{l}467 \pm 50 \\
V=13 \%\end{array}$ & $\begin{array}{l}1,4 \pm 0,2 \\
\mathrm{~V}=27 \%\end{array}$ & $\begin{array}{l}775 \pm 79 \\
\mathrm{~V}=25 \%\end{array}$ \\
\hline
\end{tabular}




\begin{tabular}{|c|c|c|c|c|c|}
\hline 1 & 2 & 3 & 4 & 5 & 6 \\
\hline \multirow{3}{*}{ 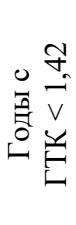 } & Новосибирский 5 & $\begin{array}{c}68.4 \pm 1,9 \\
V=7 \%\end{array}$ & $\begin{array}{c}450 \pm 26 \\
V=16 \%\end{array}$ & $\begin{array}{c}1,0 \pm 0,1 \\
V=27 \%\end{array}$ & $\begin{array}{c}574 \pm 67 \\
V=29 \%\end{array}$ \\
\hline & Новосибирский 88 & $\begin{array}{c}68.4 \pm 1,9 \\
V=7 \%\end{array}$ & $\begin{array}{c}427 \pm 22 \\
V=19 \%\end{array}$ & $\begin{array}{c}1,1 \pm 0,1 \\
V=34 \%\end{array}$ & $\begin{array}{c}489 \pm 69 \\
V=32 \%\end{array}$ \\
\hline & Ровесник & $\begin{array}{c}70.6 \pm 1,9 \\
V=7 \%\end{array}$ & $\begin{array}{c}394 \pm 26 \\
V=31 \%\end{array}$ & $\begin{array}{c}1,0 \pm 0,1 \\
V=23 \%\end{array}$ & $\begin{array}{c}523 \pm 73 \\
V=34 \%\end{array}$ \\
\hline
\end{tabular}

* в годы с ГТК $\geq 1,42$ - разность между сортами существенна при $\mathrm{P}=0,99$.

Продуктивность метелки и урожайность сортов в годы с повышенным и в годы с пониженным ГТК показали значительную степень рассеивания данных, что обусловило не существенную разность между группами. При распределении условий года на группы недостаточно использование только показателя ГТК за период развития растений, т. к. в некоторые годы с пониженным ГТК, но с равномерным распределением осадков, сорта формировали повышенную урожайность. В некоторые годы с более высоким ГТК формировалась пониженная урожайность, из-за не своевременного выпадения осадков.

Сортовые различия по формированию урожайности в разных условиях так же не существенны. Тем не менее сорт Новосибирский 88 имел наиболее высокий показатель средней урожайности в годы с $\Gamma \mathrm{TK} \geq 1,42$, а в годы с ГТК $<1,42$ показывал наименьшую урожайность, что характеризует его как сорт интенсивного типа, реализующего свой потенциал в благоприятных условиях развития растений. Сорт Новосибирский 5 имел наиболее высокий показатель средней урожайности в годы с ГТК $<1,42$, а в годы с $\Gamma \mathrm{TK} \geq 1,42$ показывал наименьшую урожайность, что характеризует его как сорт экстенсивного типа, сохраняющего свой потенциал в годы с засухой.

Выводы:

1. Отмечена сортовая специфичность по реализации потенциала урожайности в разных гидротермических условиях. Сорт Новосибирский 88 относится к интенсивному типу, а Новосибирский 5 - к экстенсивному типу.

2. При распределении условий года на группы недостаточно использование только показателя ГТК за период развития растений.

Благодарности: работа поддержана бюджетным проектом ИЦиГ СО РАH № 0324-2019-0039-C-01.

\section{Список литературы}

1. Баталова Г.А. Состояние и перспективы селекции и возделывания зернофуражных культур в России - 2011. - № 3. С. 14-22.

2. Сотник А.Я. Продуктивность и адаптивность сортов овса в условиях Приобской лесостепи // Сиб. Вестн. с.-х. науки. - 2017. - № 1 - С. 38-44.

3. Баталова Г.А. Методология создания продуктивных, эколгически устойчивых сортов овса пленчатого / Г.А. Баталова, С.Н. Шевченко, Е.М. Лисицын, М.В. Туля- 
кова, И.И. Русакова, В.А. Железникова, Т.П. Градобоева // Российская сельскохозяйственная наука. - 2017. - № 6. - С. 3-6.

4. Сортовое районирование сельскохозяйственных культур по Новосибирской области на 2019 год / Филиал ФГБУ «Госсорткомиссия» по Новосибирской области Минист.сельск. хоз. РФ. Новосибирск. 2019. 148 с.

5. Лоскутов И.Г., Ковалева О.Н., Блинова Е.В. Методические указания по изучению и сохранению мировой коллекции ячменя и овса. СПб.: ГНУ ВИР Россельхозакадемии, 2012. $63 \mathrm{c}$.

6. Доспехов Б.А. Методика полевого опыта (с основами статистической обработки результатов исследований) Б.А. Доспехов. - 6-е изд., стер. - М.: ИД Альянс, 2011. $-352 \mathrm{c}$.

DOI 10.18699/GPB2020-111

\section{Молекулярно-генетическая характеристика образцов озимой мягкой пшеницы в связи с селекцией на устойчивость к полеганию}

Сычева Е.А. ${ }^{\text {I* }}$ Бондаревич Е.Б. ${ }^{\text {, }}$ Соловей Л.А. ${ }^{1}$, Шимко В.Е. ${ }^{1}$, Гордей С.И. ${ }^{2}$, Дубовеи Н.И. ${ }^{l}$

${ }^{1}$ Институт генетики и цитологии Национальной академии наук Беларуси, 2. Минск, Республика Беларусь;

${ }^{2}$ Научно-практический центр НАН Беларуси по земледелию, г. Жодино, Республика Беларусь.

*e-mail: E.Sycheva@igc.by

Изучены кариотипы и аллельное состояние генов короткостебельности Rht-B1, Rht-D1 и Rht8 y 32 сортов и селекционных образиов озимой мягкой пшеницьл. Установлено, что 6 образиов содержат в кариотипе транслокачию $1 R S .1 B L$, у 4 образиов выявлена делеция 5BS.5BL-del. B проанализированном селекиионном материале преобладали (37,5\%) растения с генотипом Rht-Bla, Rht-D1a, Rht8b. В 18,8\% случаев присутствовал генотип Rht-B1b, Rht-Dla, Rht8b, с одинаковой частотой 9,4\% встречались геноmuпbl Rht-Bla, Rht-Dla, Rht8a / Rht-Bla, Rht-Dlb, Rht8a / Rht-Bla, Rht-Dlb, Rht8b. Генотипь Rht-B1a, Rht-Dla, Rht8c и Rht-B1a, Rht-D1b, Rht8j выявлень y $6,3 \%$ образиов.

Ключевые слова: озимая мягкая пшеница, устойчивость к полеганию, ДНК-маркеры, кариотип, С-бэндинг.

\section{Molecular Genetic Characteristics of Winter Wheat Varieties and Lines in Connection with Breeding for Lodging Resistance}

SychevaE.A. ${ }^{l}$, Bondarevich E.B. ${ }^{l}$, Solovey L.A. ${ }^{l}$, Shimko B.E. ${ }^{l}$, Gordey S.I. ${ }^{2}$, Dubovets N.I. ${ }^{1}$ 